\title{
A Bow to the Old and the New
}

$\mathrm{A}^{\mathrm{T}}$ the board of directors of A.C.R.L. accepted the resignation of Carl M. White as editor-in-chief of College and Research Libraries and, upon his recommendation, placed the mantle and full responsibility of this important editorship on the shoulders of Managing Editor Maurice F. Tauber. Dr. White, in asking to be relieved of his editorial responsibilities, paid tribute to the several managing editors who had assisted him during his six years of editorship, a period which saw the journal firmly established on sound professional lines. $\mathrm{He}$ emphasized particularly Dr. Tauber's work, saying that he had been able, with full confidence, to leave more and more of the details of editing, as well as matters of policy and principle to Dr. Tauber. Now, with everything being handled so competently, and with the journal so well established, he said, he would like to step aside in deference to Dr. Tauber.

This request and recommendation the board unanimously accepted, with a formal expression of thanks to Dr. White, for his excellent services during the formative years of the journal. Dr. Tauber, in accepting the editorship, expressed thanks for the confidence of the board in him. He spoke appreciatively of Dr. White's editorial contributions to the journal and expressed the hope that he would be able to maintain the same high standards. He also paid tribute to the editorial staff.

A review of the relatively brief history of College and Research Libraries indicates that it has indeed been fortunate in its editors. Dr. A. F. Kuhlman, who, as its first editor played an important part in setting the tone of the journal, launched the first issue with an introductory statement emphasizing the need of a journal of truly professional character. He set forth eight purposes or objectives of such a journal. College and Research Libraries has, under its several editors, fulfilled these soundly conceived purposes in very considerable degree. During the period December I 939 to June I94I this was done under Dr. Kuhlman's editorship, without the help of a managing editor. Dr. White, during his period as editor, September I94 I to January 1948, was assisted from September I94 I to September I943, by E. W. McDiarmid as managing editor. Dr. White carried the editorial responsibilities alone from December I 943 to March I944. From that time until September 1945, Ernest J. Reece served as managing editor. He was succeeded by Maurice F. Tauber who now becomes editor-in-chief.

For all of these men, editing our journal has been a labor of love, their only compensation the satisfaction of professional contribution, and of work well-done. How well their work was, in fact, done is attested by the seven volumes the journal has now attained. As one thumbs through these issues, and compares their substantial articles and their attractive and readable pages with our earlier more or less hodgepodge and tidbit literature, one gets a real and inspiring realization of professional progress and advance. For much of this we owe our past editors a real debt of gratitude. Under our new editor, and the continuing substantial sponsorship of Columbia University, all of us can look forward to a journal, which through its professional content and excellence of presentation, will assist us in our growth to the stature of a true profession.

William H. Carlson, President Association of College and Reference Libraries 